\title{
FACTORS AFFECTING CHINESE TOURIST'S LOYALTY TOWARDS HO CHI MINH CITY - A MEDIATION ANALYSIS OF TOURISTS' PERCEIVED VALUE
}

\author{
MAI NGOC KHUONG \\ International University, Vietnam National University HCMC - Email: mnkhuong@ hcmiu.edu.vn \\ NGUYEN TRAN NGUYEN KHAI \\ International University, Vietnam National University HCMC - Email: khainguyenminh@gmail.com
}

DO AI DAO

International University, Vietnam National University HCMC - Email: doaidao0604@ gmail.com

(Received: September 1, 2016; Revised: September 23, 2016; Accepted: October 10, 2016)

\begin{abstract}
The purpose of this research was to examine empirically the causal relationships among push factors, pull factors, risk perception, tourists' perceived value and loyalty of Chinese tourists travelling to Ho Chi Minh City. A survey was conducted investigating 470 Chinese tourists to collect the primary data. As a result, Chinese tourists' loyalty towards Ho Chi Minh City could be predicted by some of their push motivation, pull motivation and their perceived value about the trip or tourists' services received. Consequently, business organizations and tourism companies should consider the crucial roles of push and pull factors to attract more potential repeated visitors and increase their perceived value and loyal to Vietnam, especially to Ho Chi Minh City in the near future.
\end{abstract}

Keywords: Pull factors; Push factors; Risk perception; Tourists' loyalty; Tourists' perceived value.

\section{Introduction}

Recognizing the important role of tourism industry, Vietnam has attempted to invest and develop the industry in recent years and gained some achievements. In 2015, Vietnam's tourism made remarkable achievements and maintained its stability regardless of challenges in international political and economic situation and difficulties in domestic situation. International tourist arrivals to Viet Nam in November 2015 were estimated at 760,798 visitors, an increase of $2.6 \%$ over the previous month and $15 \%$ over the same period last year. Total international tourist arrivals for 12 months reached $7,943,651$ people, increasing by $0.9 \%$ over the same period last year (VNAT, 2015).

Remarkably, Ho Chi Minh City, one of the largest cities and most popular destinations in Vietnam, has attracted many international visitors. According to VNAT (2016), Ho Chi Minh City attracted more than 4.6 million international arrivals, a year-onyear rise of $13 \%$, and created tourism revenues of VND 94.6 trillion, a rise of $10 \%$ compared to last year. The aforementioned data showed a significant contribution of tourism industry to the country's economy and promised a great potential in the development of Vietnam's tourism in general and Ho Chi Minh City's tourism in particular.

Of all international visitors travelling to Vietnam, Chinese tourists took up the highest rate in terms of visitors with total arrivals in the whole year of 2015 of $1,780,918$ people, a decrease of $9.5 \%$ compared to the same period last year (VNAT, 2015). Not only did Chinese tourists reach record high in terms of total arrival, they also reach the highest rate in terms of consumption value. According to 
World Tourism Cities Federation (2014), Chinese tourists spent 128.7 billion dollars abroad in 2013 including $23 \%$ and $10 \%$ on luxury goods in Europe and the US respectively, an increase of $26.8 \%$ over 2012 . With such travelling and spending habits, Chinese tourists could be regarded as a potential target market for Vietnam's tourism.

The number of Chinese tourists travelling to Ho Chi Minh City had the potential of increasing year after year. Additionally, Ho Chi Minh City had many tourism potentials such as many beautiful sightseeing places, famous historic relics, natural and cultural heritages together with diversified cuisines and recreational activities. However, Vietnam tourism has faced some tough challenges such as keen competition from other ASEAN countries, lack of awareness among people, poor infrastructure system, as well as some unfruitful governmental policies to make Viet Nam a more competitive destination. Many tourists just came to Viet Nam or Ho Chi Minh City once and do not return as they prefer other destinations.

This research focused on studying Chinese tourists from China (Beijing, Shanghai, Tianjin, Hong Kong, Guangdong, etc.), and from Chinese-speaking countries like Taiwan travelling to Ho Chi Minh City. The participants consisted of both females and males; and both first time and repeat visitors.

\section{Literature Review}

\section{Tourists' Loyalty}

According to Oliver (1997), loyalty referred to the repeat purchase commitment of products or services regardless of the influences of situation or marketing efforts directed at causing changes in consumers' behavior. The destination loyalty was regularly reflected in tourists' intention to revisit the destination (Oppermann, 2000). Moreover, loyalty was conceptualized from these three main perspectives: behavioral, attitudinal and compound (Bowen \& Chen, 2001; Zins, 2001). Behavioral loyalty was reflected in repeat purchase, attitudinal loyalty includes recommending the service provider to others and repurchase intentions, and compound loyalty combined both components, predicting the construct better (Dimitriades, 2006; Pritchard \& Howard, 1997). In addition, this research also investigated loyalty in the tourism context which was defined as the tourists' intention to re-visit or return to any destinations.

Visitors' loyalty had become a key element for destination marketers and management researchers (Lee, Graefe, and Burns, 2007). Retention of loyal customers brought several benefits for a destination. Firstly, the marketing costs needed to attract repeat visits were normally lower than those to recruit new tourists (Lindgreen, Davis, Brodie, and Buchanan-Oliver, 2000; Oppermann, 1998). Secondly, tourists returning to a destination were a positive sign of their satisfaction (Oppermann, 1998). Thirdly, repeat visitors form a stable tourist market. Lastly, they also provided free advertising in the form of word-of-mouth recommendations to other potential tourists (Reid \& Reid, 1993; Anderson \& Mittal, 2000; Oppermann, 2000; Bowen \& Chen, 2001; Lau \& McKercher, 2004). Due to the importance of the visitors' loyalty for a destination, both academics and practitioners had attempted to explore the most prominent previous research and factors, which most affected tourist loyalty to increase the probability of repeat visitors.

\section{Tourists' Perceived Value}

Tourist perceived value was defined as the overall evaluation of consumers about the usefulness of any products that was based on the awareness of the thing they was received and the thing they was given (Zeithaml, 1988). Zeithaml (ibid) further claimed that tourist' perceived value was a comprehensive construct involving both price variations and psychological factors. Tourist perceived value might vary extensively depending on the types of products and services that were offered as well as on various consumers' characteristic (Zeithaml, ibid).

In recent years, several studies in the area 
of tourism and hospitality had been done to examine how the tourist's perceived value might impact on different aspects of consumer behavior. Schiffman and Kanuk (2004) claimed that the main objective of providing value to clients and making an organization more effective than their competitors was to have and to retain highly satisfied client. The empirical study of tourist perceived value showed that it was more relatively significant and comprehensive when putting in the tourism context than in other settings (Gallarza \& Saura, 2006).

\section{The Factors Affect to Tourists' Loyalty}

This study emphasized three main factors which might affect tourists' expectation: push factor, pull factor and risk perception. The concept of push and pull travel motivation factors had become one of the most popular and helpful frameworks to study and examine tourists' behaviors. These two factors explained that people decided to travel because they were pushed by their own internal motivation and pulled by the external motivation from characteristic of the destination. Push factors referred to the motivation that pushed a person from home or one destination to travel to another destination, pull factors were the motivation that pull individuals towards a specific destination. Moreover, this research also conducted an in-depth exploration about the negative attribute - risk perception - which might or might not affect tourists' loyalty. The features of each motivation factor created an in-depth discussion as below.

According to Crompton (1979), the push factors consisted of seven socio-psychological motivation (including 'escape', 'selfexploratory', 'relaxation', 'prestige', 'regression', 'kinship enhancement', and 'social interaction') and two other cultural motivations (novelty and education). These push factors were regarded as extremely important factors to help us understand the reason for tourists to take a holiday and their behaviors. Push factors helped a person build the desire to make a holiday and was regarded as a specific motivation that caused him to take a vacation (Goossens, 2000). This research also highlighted the four factors of the push motivation: self-exploratory, relaxation, prestige, and social interaction.

According to Crompton (1979), pull factors were tangible resources and traveler's perception and expectation for the included features, attractions, or attributes of a specific destination of choice. Pull factors were external forces that correlated to the natural and historic attractions, food, people, recreation services, and marketed image of the destination (Uysal \& Jurowski, 1994). Pull factors influenced the choice of a destination and the reference made by using those factors would lead to the selection of a destination once the decision of travel had been made (Klenosky, 2002). This research deeply examined pull factors including the following 6 main factors: destination image; natural environment; infrastructure and accessibility; cultural, history and art; entertainment, recreation and other activities; local cuisine.

According to the literature of consumer behaviors, perceived risk was a multidimensional construct including several primary risk facets: equipment, financial, physical, satisfaction, social, psychological, and moment in time (Kaplan, Szybillo, and Jacoby, 1974). Previous research had confirmed that perceptions of risk and safety could directly influence tourists' destination choice as well as their probability to visit or avoid certain destinations, particularly areas which safety was uncertain (Sonmez \& Graefe, 1998a). This factor was divided into three small factors: destination related risk, physical risk, and travel related risk. This aimed to have an in-depth understanding about the risks that really affected tourists' perceived value or loyalty. Destination related risk comprised of items such as the reactions of family and friends toward the trip, the compatibility of the trip with the individual's self-image and personality, difficulties in communicating and adapting with the culture of the destination, and the locals' attitudes 
toward international tourists that leads to an unpleasant experience (Dolnicar 2005; Fuchs $\&$ Reichel 2006b). Physical risk consisted of many factors such as food safety, infectious diseases, natural disasters, car accidents, crime, terrorism, and political turmoil (Mitchell \& Vassos, 1997; Maser \& Weiermair, 1998; Fuchs \& Reichel 2006b). Travel related risk included the factors that related to equipment and conditional problems or troubles like bad weather, transport breakdown, inappropriate company, and misuse of time and money (Fuchs \& Reichel, 2006b; Reisinger \& Mavondo, 2006).

\section{Methodology}

\section{Research proposed framework}

With the importance of push, pull factors and risk perception to the tourism, this research proposed a model of 13 independent factors, of which there are 4 pull factors, 6 pull factors and 3 risk perception factors that might affect Chinese tourists' loyalty and perceived value.

To confirm the direct and indirect effects of push, pull, perceived risk factors, and perceived value on tourists' loyalty, this study hypothesized that:

$\mathrm{H}_{1}$ : Push factors, pull factors, and risk perceived factors directly affect tourists' perceived value

$\mathrm{H}_{2}$ : Push factors, pull factors, risk perceived factors, and tourists' perceived value directly affect tourists' loyalty

$\mathrm{H}_{3}$ : The effects of push factors, pull factors, and risk perceived factors on tourists' loyalty is mediated by tourists' perceived value

\section{Questionnaire Design and Data Collection}

Because the study aimed to identify factors affecting Chinese tourists' loyalty when travelling to Ho Chi Minh City, questionnaire was considered as the most appropriate research instrument. The questionnaire was built based on major concepts and variables, which were mentioned in the literature review section. In order to ensure the reliability and validity of all scales of the research, all questions were raised as suitable as possible. Most of questions were designed and formulated based on a five-point Likert-scale ranging from 1 to 5 , equivalent to $1=$ Strongly disagree, $2=$ Disagree, $3=$ Neutral, $4=$ Agree and 5 = Strongly agree. The original questionnaire was firstly written in English, and then was translated to Chinese; written in the simple Mandarin form to make it easier and more understandable for Chinese respondents.

Primary data was the main data source for analysis, which was obtained directly from Chinese tourists travelling to Ho Chi Minh. The data was collected by two ways: (1) gave questionnaire directly to the target respondents and (2) did online survey by sending questionnaire link to respondents through email and Facebook. Some respondents were approached by tour guides, restaurant and hotel servants at various tourist attractions in the center of Ho Chi Minh City, such as Ben Thanh Market, the Unification Palace, Museum of War Remnant, etc.; and in District 5. The respondents were also given incentives (a pen with a yellow ribbon bow) to reduce the rejection rate.

\section{Sample Background}

Through the data collection process, 470 responses were collected from Chinese tourists with $61.3 \%$ female and $38.7 \%$ male. Most of the respondents were from age of 41 to $60(31.1 \%)$, followed by $31-40$ age group (28.5\%), 26-30 age group (19.8\%), above 60 $(7.2 \%), 18-25$ age group $(7 \%)$ and below 18 $(6.4 \%)$. The data implied what potential customers of Vietnam tourism like. Generation Y or millennial could be lucrative market in the long run but at the present Generation $\mathrm{X}$ is the main segment that tourism industry should focus on. Besides, the sample recognized that $36.4 \%$ of the respondents have college degree, $45.3 \%$ is studying or completed university degree and $5.7 \%$ has master degree or higher. Accordingly, tourist businesses should have a very special and systematic business plan to be able to meet these well-educated tourists' 
needs. Moreover, nearly half of the respondents $(49.1 \%)$ have visited Ho Chi Minh City twice and $30.9 \%$ of them came to the city for the first time. Surprisingly, 77 Chinese tourists came three times $(16.4 \%)$ and 17 more than three times $(3.6 \%)$. These figures show that Ho Chi Minh City has become more and more popular among Chinese tourists.

\section{Research Findings \\ Factor Analysis and Reliability}

In this study, Exploratory Factor analysis (EFA) was applied twice for the groups of independent and dependent variables. For independent variables, the KMO measure of sampling adequacy $(\mathrm{KMO}=.793)$ and Bartlett's test of Sphericity was significant $(\mathrm{Sig}=.000)$. Therefore, this factor analysis was considered appropriate. In the table of Total Variance Explained, these factors accounted for $72 \%$ of the total variance, which was higher than $50 \%$.

Table 1

Summary of Independent Variables with Reliability Coefficients

\begin{tabular}{|c|c|c|c|c|}
\hline & Given Names & Type of factor & $\begin{array}{l}\text { No. of } \\
\text { Items }\end{array}$ & Alpha \\
\hline Factor 1 & Self-exploratory (SELEXPLO) & PUSH & 5 & .911 \\
\hline Factor 2 & Relaxation (RELAX) & PUSH & 5 & .863 \\
\hline Factor 3 & Prestige (PRESTI) & PUSH & 4 & .910 \\
\hline Factor 4 & Social Interaction (SOCINT) & PUSH & 5 & .962 \\
\hline Factor 5 & Destination Image (DESIMA) & PULL & 6 & .927 \\
\hline Factor 6 & Natural Environment (NATENVI) & PULL & 4 & .771 \\
\hline Factor 7 & Infrastructure and Accessibility (INFRACES) & PULL & 5 & .827 \\
\hline Factor 8 & Cultural, History and Art (CULHISA) & PULL & 5 & .903 \\
\hline Factor 9 & $\begin{array}{l}\text { Entertainment, Recreation and Other activities } \\
\text { (ENRENOT) }\end{array}$ & PULL & 5 & .761 \\
\hline Factor 10 & Local Cuisine (LOCUIS) & PULL & 5 & .882 \\
\hline Factor 11 & Destination Related Risk (DERERIS) & $\begin{array}{c}\text { RISK } \\
\text { PERCEPTION }\end{array}$ & 5 & .907 \\
\hline Factor 12 & Physical Risk (PHYRIS) & $\begin{array}{c}\text { RISK } \\
\text { PERCEPTION }\end{array}$ & 5 & .891 \\
\hline Factor 13 & Travel Related Risk (TRARERIS) & $\begin{array}{c}\text { RISK } \\
\text { PERCEPTION }\end{array}$ & 5 & .920 \\
\hline
\end{tabular}

The second Exploratory Factor Analysis was conducted for the group of two dependent variables. The KMO and Bartlett's test of sphericity and Varimax Rotation were applied for 6 tourists' perceived value attributes and 4 tourists' loyalty attributes. Based on the finding, the $\mathrm{KMO}=.820$ and Bartlett's test of sphericity Sig $=.000$ satisfied the initial conditions of EFA. Components were retained only when they had the initial eigenvalues of 1 or higher. These factors accounted for $59 \%$ of the total variance, which was higher than $50 \%$. 
Table 2

Summary of Dependent Variables with Reliability Coefficients

\begin{tabular}{llcc}
\hline \hline & Given Names & No. of Items & Alpha \\
\hline Factor 14 & Tourists' Loyalty (TOLOY) & 4 & .725 \\
Factor 15 & Tourists' Perceived Value (PERVA) & 6 & .859 \\
\hline \hline
\end{tabular}

\section{Factors Affecting Tourists' Perceived} Value and Tourists' Loyalty

In the Pearson's Correlation Analysis, the strength and direction of association between Independent Variables and Tourists' Loyalty were examined. The finding indicated the positive correlation between three independent variables (SOCINT, SELEXPLO, and RELAX) and TOLOY, with $\mathrm{r}=.147, \mathrm{p}<.01 ; \mathrm{r}=.164, \mathrm{p}<.01 ;$ and $\mathrm{r}=.139$, $\mathrm{p}<.01$ respectively; and negative correlation between two independent variables (INFRACES; NATENVI and PERVA) and TOLOY with $\mathrm{r}=-.151, \mathrm{p}<.01 ; \mathrm{r}=-.195$, $\mathrm{p}<.01$; and $\mathrm{r}=-.102, \mathrm{p}<.05$ respectively. This means the stronger SOCINT, SELEXPLO, and RELAX the travelers had, the higher Loyalty degree they felt; and the stronger INFRACES, NATENVI and PERVA Ho Chi Minh City had, the lower Loyalty degree travelers felt. Moreover, in the Linear Regression Analysis, the $\mathrm{R}$ squared value of the model was .139. It meant the model could explain $13.9 \%$ the variation of Tourists' Loyalty.

\section{Indirect Effects of Tourists' Loyalty}

The results of multiple regression analysis indicated that tourists' perceived value was significantly affected by four out of thirteen independent variables: SELEXPLO $(\beta=.090, p<.05)$, RELAX $(\beta=.110, p<.05)$, ENRENOT $(\beta=.367, p<.05)$, and NATENVI $(\beta=.222, \quad \mathrm{p}<.05)$. In addition, tourists' perceived value had a direct effect on tourists' loyalty $((\beta=-.129, \mathrm{p}<.05)$. Therefore, through the intervening variable, SELEXPLO, RELAX, ENRENOT, and NATENVI had indirect effects on tourists' loyalty at $(\beta=-$ $.012),(\beta=-.014),(\beta=-.047)$, and $(\beta=-.029)$.

\section{Significance of the Indirect Effects}

Table 3 shows the results of the bootstrapping method recommended by Preacher and Hayes (2008) to test the significance of indirect effects or mediations. The output provided the bootstrapped confidence intervals (at the 95\%). If there is a ZERO (0) lies within the interval range between the lower boundary (LL) and the upper boundary (UL), then we can conclude that, with $95 \%$ confidence, there is no mediation or indirect effect. On the other hand, if zero does not occur between the LL and the UL, then we can conclude that, with 95\% confidence, the mediation or indirect effect is significant (Preacher and Hayes, 2004). As can be seen in the output of Table 4, the indirect effects of SELEXPLO, RELAX, ENRENOT, and NATENVI on TOLOY through the mediation of PERVA were estimated to lie between -.0236 (LL) and -.0027 (UL), -.0275 (LL) and -.0040, -.0785 (LL) and -.0184 (UL), and -.0502 (LL) and .0109 (UL) with $95 \%$ confidence, respectively. Because zero is not in the $95 \%$ confidence interval, we can conclude that the indirect effects of SELEXPLO, RELAX, ENRENOT and NATENVI on TOLOY were indeed significantly different from zero at $\mathrm{p}$ $<.05$ (two tailed) and the mediation of PERVA in this study was true. 


\section{Table 3}

Direct, Indirect and Total casual effects

\begin{tabular}{lccccc}
\hline \multirow{2}{*}{ Variables } & \multicolumn{5}{c}{ Casual Effects } \\
\cline { 2 - 5 } & Direct & Indirect & Total & LL & UL \\
\hline SELEXPLO & .083 & -.012 & .071 & -.0236 & -.0027 \\
\hline RELAX & .111 & -.014 & .097 & -.0275 & -.0040 \\
\hline ENRENOT & .175 & -.047 & .128 & -.0785 & -.0184 \\
\hline NATENVI & -.139 & -.029 & -.168 & -.0502 & -.0109 \\
\hline SOCINT & .083 & - & .083 & & \\
\hline INFRACES & -.090 & - & -.090 & & \\
\hline PERVA & -.129 & - & -.129 & & \\
\hline \hline
\end{tabular}

The Causal Effects of Tourists' Loyalty

According to the result, the NATENVI factor had the strongest effect on Tourists' Loyalty of Chinese tourists surveyed, with $\beta=$ .168 , followed by Tourists' Perceived Value with $\beta=-.129$; ENRENOT factor with $\beta$ $=.128 ;$ RELAX factor with $\beta=.097$;
INFRACES factor with $\beta=-.090$; SOCINT factor with $\beta=.083$. The SELEXPLO factor had the weakest effect on their Loyalty towards Ho Chi Minh City with $\beta=.071$ only. Finally, the total effect of these factors on Tourists' Loyalty was -.008 .

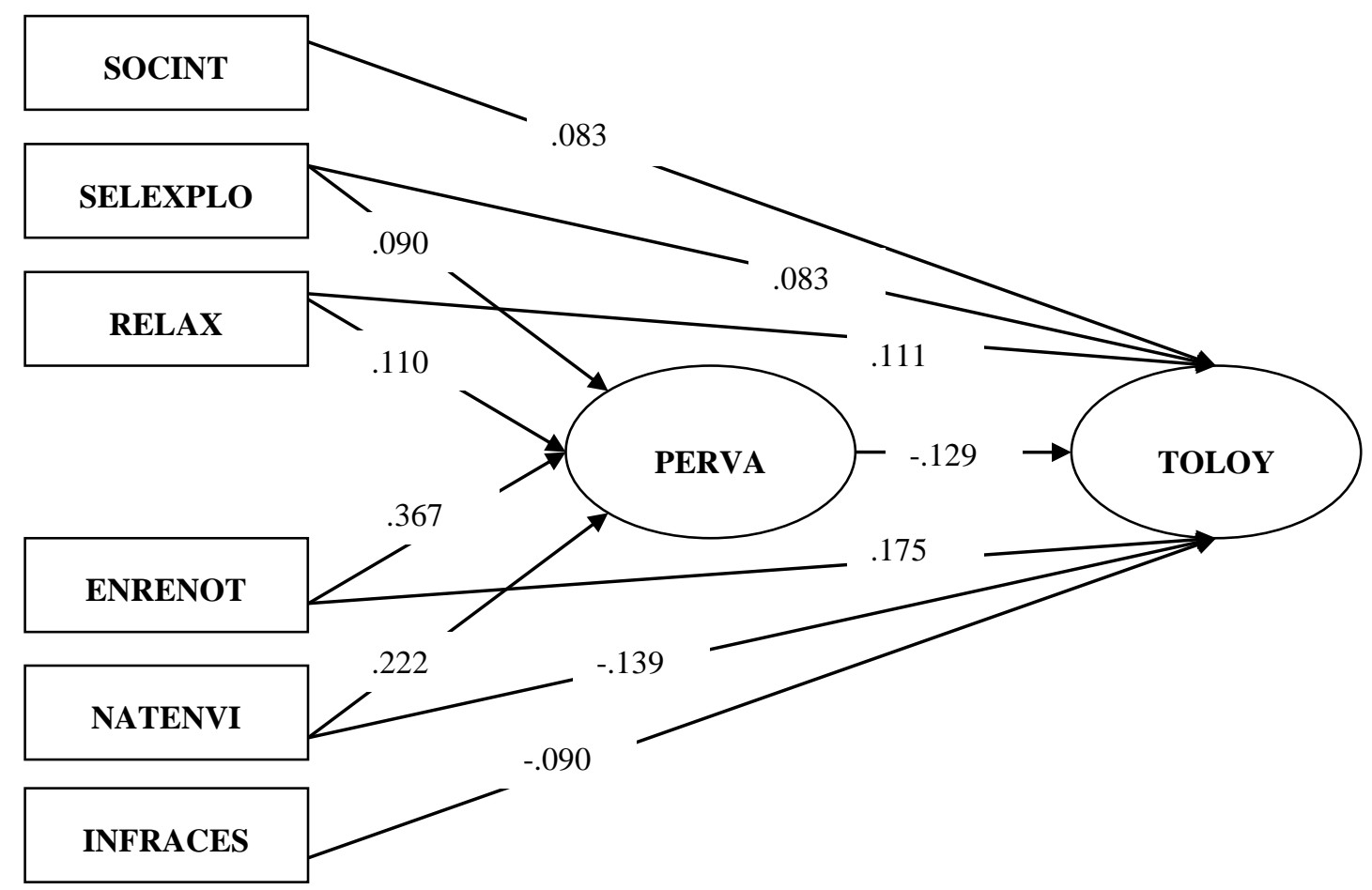

Figure 1. Path Coefficients of the Structural Equation for Hypothesis Testing 


\section{Discussion and Recommendations \\ Discussion}

According to figure 1, the dependent variable - Tourists' Loyalty was directly affected by seven factors: Social Interaction $(\beta=.083)$; Self-exploratory $(\beta=.083)$; Relaxation $(\beta=.111)$; Entertainment, Recreation and Other Activities $(\beta=.175)$; Natural Environment $(\beta=-.139)$; Infrastructure and Accessibility $(\beta=-.090)$ and Tourists' Perceived Value $(\beta=-.129)$ at the $95 \%$ confidence level, which answered Hypothesis 2, and $13.9 \%$ the variation of Tourists' Loyalty could explained by these factors $\left(\mathrm{R}^{2}=.139\right)$.

The two main factors that directly affect Chinese Tourist Loyalty are Relaxation factor and Entertainment, Recreation and Other activities factor showing the importance of both pull and push factors in tourism industry. Tourists look for destinations that can make them feel relaxed and of course such destinations need to have special and unique selling points in terms of entertainment, nightlife, recreation, etc. It suggests policymakers to encourage business, and change image of Vietnam to an active, interesting and fun destination with various activities for tourists.

Only 13.9 percent of the variance in the TOLOY could be explained by six out of thirteen independent variables. This research covered many factors; however, the $\mathrm{R}$ square value was not high. It means there might be some other factors relating to Vietnamese demographic or Vietnamese family/relative characteristics that could affect Chinese tourists' loyalty. Many Chinese tourists travelling to Ho Chi Minh City because their relatives are living here; therefore, further research studying Chinese tourists' loyalty should focus more on other different factors to increase the percent that could be explained.

Moreover, by conducting Path Analysis, the indirect impacts of Independent Variables on Tourists' Loyalty through Tourists' Perceived Value were also illustrated, with Self-exploratory ( $\beta=-.012)$; Relaxation $(\beta=-.014)$; Entertainment, Recreation and Other Activities $(\beta=-.047)$; and Natural Environment $(\beta=-.029)$, which answer Hypothesis 3. For total effects, Natural Environment had the strongest effect on Chinese Tourists' Loyalty with $\beta=-.168$.

Therefore, push motivation combined with pull motivation and the perceived value to the trip of the Chinese tourist could help predict their loyalty towards Ho Chi Minh City. The findings of this research were partially similar to the results of research made by Allan (2011); Cam (2011); Chang, (2013); and Khuong and $\mathrm{Ha}$ (2014). However, the results of this study also provide some negative correlations between Tourists' Loyalty and Tourists' Perceived Value and two pull motivation (Natural Environment; and Infrastructure and Accessibility), which create a slight difference from other previous studies.

In comparison with Cam's research (2011), some significant differences were found. In her findings, local food, environment and socio cultural factors were attractive to tourists travelling to Nha Trang while factors such as leisure, entertainment, infrastructure and accessibility were unattractive to them. On the contrary, this research found that such factors have some effect on Chinese tourists' perceived value and loyalty.

Moreover, Khuong and Ha (2014) found some slight different results by examining larger and more diversified target respondents including international leisure tourists (England, American, Chinese, French, Japanese, and Korean) traveling to the same destination, Ho Chi Minh City. Their findings showed that pull factors had significant and positive influence on tourists' destination and return intention to Vietnam. This was contrast to this research's findings due to different target respondents between the two studies.

The negative effect between Tourists' Loyalty and Tourists' Perceived Value or 
Tourists' Loyalty and two pull motivations (Natural Environment, Infrastructure and Accessibility) might result from the fact that the research target respondents were mostly Chinese visitors travelling not only for tourism purposes but also for doing business or visiting relatives. Noticeably, some of the respondents were businessman or investors who want to invest in Ho Chi Minh City. The less quality of Ho Chi Minh City natural environment and infrastructure \& accessibility, the less Chinese visitors perceived value to Ho Chi Minh City; the more loyalty Chinese visitors had towards Ho Chi Minh City to improve or invest, which depend very much on their aims of travelling to Ho Chi Minh City.

\section{Recommendations for Ho Chi Minh's Tourism}

Based on these results, the research provides local tourism policymakers with some constructive recommendations for raising Chinese tourists' loyalty as they travel to the city.

Firstly, Vietnam destination marketers should invest more in impressive tourism advertisements and attractive promotional programs to boost potential customers' travel motivation. Investing in tourism websites and video clips with diversified tourist information and images may also be effective ways to introduce Vietnam's destinations to foreigners. Tourism organizations must create a positive atmosphere and build up good relationships with customers before, during and after a visit. The term "after" means that the organization should recreate an experience of satisfaction for tourists and make them desire to return and, at the same time, recall the memorable moments they have had about the destination.

Secondly, tourist agents should diversify vacation packages and develop destination programs and activities to provide tourist with more choices. They should be more flexible in designing and providing tourist products and services. Besides, they need to get well prepared for alternative activities or plans to meet the different customers' needs and to offer interesting and unforgettable tourism experiences. Tourist companies should cooperate with some recreational areas to offer tourists more exciting activities (cooking classes, sports, sailing, golf, etc.) and combine with special events or traditional holidays with special deal or discounts. Furthermore, more special events and festivals (about culture, sport or shopping, etc.) should be hold to attract more inbound tourists and impress them during a trip to the city.

Finally, factors such as natural environment, infrastructure \& accessibility system had negative effect on Tourists' Loyalty. The reason was probably that some research respondents are Chinese travellers who wanted to invest in Ho Chi Minh City. Ho Chi Minh City's natural environment, infrastructure and accessibility system were generally good but not good enough for Chinese visitors to build up their loyalty toward the city so that they can return, start up their business and invest in the city. If these assumptions were true, Ho Chi Minh City's government should have some encouraging moves to build trust in foreign investors. Also, the city's administrative system should spend more time and money improving their service. The tourism managers need regularly check and update the state of all restaurants, hotels and entertaining places (such as bars, movie theaters, karaoke or shopping stores, etc.) in the city to make sure that they are in good condition. If any problems or damaged things are detected, they will need to be repaired immediately.

\section{Conclusion}

In summary, this study sought to provide overall understanding about the tourism industry of Ho Chi Minh City and to recommend some methods to measure tourists' loyalty by identifying all independent and significant factors that directly or indirectly affected their loyalty. By analyzing the information collected from 470 respondents 
who travelled to Ho Chi Minh City, the research discovered some valuable results.

Seven factors significantly affecting Chinese tourists' loyalty include: (1) Social Interaction, (2) Self-exploratory, Relaxation; (4) Entertainment, Recreations and Other Activities; (5) Natural Environment; (6) Infrastructure and Accessibility and (7) Tourists' Perceived Value. Especially, of which Entertainment, Recreations and Other Activities was the most important factor greatly affecting tourists' loyalty with the largest beta value (.175), followed by Natural Environment; Tourists' Perceived Value; Relaxation; Infrastructure and Accessibility; Social Interaction; and Self-exploratory with $\beta=-.139 ;-.129 ; .111$; $.09 ; .083$ and .083 respectively.
There were 4 factors held positive beta value, which meant the better Entertainment; Recreations and Other Activities; Relaxation; Social Interaction; Self-exploratory; the more loyalty Chinese tourist would have towards Ho Chi Minh City. In contrary, there were 3 factors that held negative beta value, which meant the lower Natural Environment; Tourists' Perceived Value; Infrastructure and Accessibility; the more loyalty Chinese tourist would have towards Ho Chi Minh City.

Based on these results, the research provided some constructive recommendations for local tourism policy-makers to raise the loyalty of Chinese tourists coming to this destination, which might contribute to the success of tourism industry of Ho Chi Minh City

\section{References}

Allan, M. (2011). Toward a better understanding of motivations for a geotourism experience: A self-determination theory perspective. (Doctoral Dissertation). Retrieved from http://ro.ecu.edu.au/theses/438/.

Anderson, E. W. \& Mittal, V. (2000). Strengthening the satisfaction - profit chain. Journal of Service Research, 3(2), 107-120. doi: 10.1177/109467050032001

Bowen, J. \& Chen, S. (2001).The relationship between customer loyalty and customer satisfaction. International Journal of Contemporary Hospitality Management, 13(5), 213-217. doi: http://dx.doi.org/10.1108/09596110110395893

Cam, T. T. A. (2011). Explaining tourists satisfaction and intention to revisit Nha Trang, Viet Nam. (Master thesis). Retrieved from http://hdl.handle.net/10037/3782/.

Chang, L. (2013). Influencing Factors on Creative Tourists' Revisiting Intentions: The Roles of Motivation, Experience and Perceived Value. Dissertations. Paper 1084. http://tigerprints.clemson.edu/all_dissertations/1084/.

Crompton, J. (1979). Motivations for pleasure vacations. Annals of Tourism Research, 6(4), 408-424.

Dimitriades, Z. S. (2006). Customer satisfaction, loyalty and commitment in service organizations. Management Research News, 29(12), 782-800. doi: http://dx.doi.org/10.1108/01409170610717817

Dolnicar, S. (2005). Understanding Barriers to Leisure Travel: Tourist Fears as a Marketing Basis. Journal of Vacation Marketing, 11(3), 197-208. doi: 10.1177/1356766705055706

Fuchs, G. \& Reichel, A. (2006b). Tourist Destination Risk Perception: The Case of Israel. Journal of Hospitality and Leisure Marketing, 14 (2), 83-108. doi: 10.1300/J150v14n02_06

Gallarza, M. G. \& Saura, I. G. (2006). Value dimensions, perceived value, satisfaction and loyalty: an investigation of university students' travel behavior. Tourism Management, 27(3), 437-452. doi:10.1016/j.tourman.2004.12.002

Ghazizadeh, M., Besheli, A. L. \& Talebi, V. (2010). Assessing of bank customers retention and loyalty: a case study of state-owned banks in Tehran. European Journal of Social Sciences, 17(2), 274-287. 
Goossens, C. (2000). Tourism information and pleasure motivation. Annals of tourism research, $27(2), 301-321$. doi: 10.1016/S0160-7383(99)00067-5

Hair, J. F. Jr., Black, W. C., Babin, B. J., Anderson, R. E. \& Tatham, R. L. (2006). Multivariate data analysis, 6th edition. New Jersey: Prentice Hall.

Harwood, M. (2002). Branding on a budget: building the community bank's image. Community Banker, 11(4), 2428.

Preacher, J. K. and Hayes, A. F. (2008). Asymptotic and re sampling strategies for assessing and comparing indirect effects in multiple mediator models. Behavior Research Methods, 40(3), 879-891. doi: 10.3758/BRM.40.3.879

Preacher, J. K. and Hayes, A. F. (2004). SPSS and SAS procedures for estimating indirect effects in simple mediation models. Behavior Research Methods, Instruments, \& Computers, 36(4), 717-731. doi: $10.3758 / \mathrm{BF} 03206553$

Kaplan, L. B., Geogre, J. S., and Jacoby, J. (1974). Components of Perceived Risk in Product Purchase: A Cross Validation. Journal of Applied Psychology, 59(3), 287-291. doi: http://dx.doi.org/10.1037/h0036657

Khuong, M. N., and Ha, H. T. T. (2014). The Influences of Push and Pull Factors on the International Leisure Tourists' Return Intention to Ho Chi Minh City, Vietnam - A Mediation Analysis of Destination Satisfaction. International Journal of Trade, Economics and Finance, 5(6), 490-496. doi: 10.7763/IJTEF.2014.V5.421

Klenosky, D. B. (2002). The pull of tourism destinations: a means-end investigation. Journal of travel research, 40(4), 396-403. doi: 10.1177/004728750204000405

Lau, A. L. S. \& McKercher, B. (2004). Exploration versus acquisition: A comparison of first time and repeat visitors. Journal of Travel Research, 42(3), 279-285. doi: 10.1177/0047287503257502

Lee, J., Graefe, A. R., \& Burns, R. C. (2007). Examining the antecedents of destination loyalty in a forest setting. Leisure Sciences: An Interdisciplinary Journal, 29(5), 463-481. doi: 10.1080/01490400701544634

Lindgreen, A., Davis, R., Brodie, R. J., \& Buchanan-Oliver, M. (2000). Pluralism in contemporary marketing practices. International Journal of Bank Marketing, 18 (6), 294-308. doi: http://dx.doi.org/10.1108/02652320010358715

Maser, B., \& Weiermair, K. (1998). Travel Decision- Making: From the Vantage Point of Perceived Risk and Information Preferences. Journal of Travel and Tourism Marketing, 7(4), 107-21. doi: 10.1300/J073v07n04_06

Mitchell, V. W. \& Vassos, V. (1997). Perceived Risk and Risk Reduction in Holiday Purchases: A Cross- Cultural and Gender Analysis. Journal of Euromarketing, 6(3), 47-79. doi: 10.1300/J037v06n03_03

Oliver. (1997). Satisfaction: A Behavioral Perspective on the Consumer. New York: The McGraw-Hill Companies, Inc.

Oppermann, M. (1998). Destination threshold potential and the law of repeat visitation. Journal of Travel Research, 37(2), 131-137. doi: 10.1177/004728759803700204

Oppermann, M. (2000). Tourism destination loyalty. Journal of Travel Research, 39(1), 78- 84. doi: $10.1177 / 004728750003900110$

Pritchard, M. \& Howard, D. R. (1997). The loyal traveler: examining a typology of service patronage. Journal of Travel Research, 35(4), 2-10. doi: 10.1177/004728759703500417.

Reid, L. \& Reid, S. (1993). Communicating tourism supplier services: Building repeat tourist relationships. Journal of Travel and Tourism Marketing, 2(2/3), 3-19. doi: 10.1300/J073v02n02_02

Reisinger, Y. \& Mavondo, F. (2006). Cultural Differences in Travel Risk Perception. Journal of Travel and Tourism Marketing, 20(1): 13-31. doi: 10.1300/J073v20n01_02

Schiffman, G. L. \& Kanuk, L. L. (2004). Consumer Behavior. Pearson Education, Inc. 
Sonmez, S. F., and Graefe, A. R. (1998a). Determining Future Travel Behavior from Past Travel Experience and Perceptions of Risk and Safety. Journal of Travel Research, 37(2), 171-177. doi: $10.1177 / 004728759803700209$

Tabachnick, B. G., \& Fidell, L. S. (2001). Using multivariate statistics, 4th edition. New York: HarperCollins.

Uysal, M. \& Jurowski, C. (1994). Testing of the push and pull factors. Annals of Tourism Research, 21(4), 844-846. doi:10.1016/0160-7383(94)90091-4

VNAT - Vietnam National Administration of Tourism. (December 28, 2015). International visitors to Vietnam in December and 12 months of 2015. Retrieved from http://vietnamtourism.gov.vn/english/index.php/items/9968.

VNAT - Vietnam National Administration of Tourism. (January 15, 2016). HCM City targets 5.1 million international visitors in 2016. Retrieved from http://vietnamtourism.gov.vn/english/index.php/items/10030.

World Tourism Cities Federation. (December 09, 2014). Market Research Report on Chinese Outbound Tourist (City) Consumption. Retrieved from http://en.wtcf.org.cn/2014-09/12/c_27384.htm/.

World Travel \& Tourism Council. (March 2016). 2016 Economic Impact Annual Update Summary. Retrieved from http://www.wttc.org/research/economic-research/economic-impact-analysis/.

Zeithaml, V. A. (1988). Consumer perceptions of price, quality, and value: a means-end model and synthesis of evidence. Journal of Marketing, 52(3), 2-22. doi: 10.2307/1251446

Zins, A. H. (2001). Relative attitudes and commitment in customer loyalty models. International Journal of Service Industry Management, 12(3), 269-294. doi: http://dx.doi.org/10.1108/EUM0000000005521 